\title{
Nunggak Semi Al Suwardi: Organology and Perspective of Harmonic Planet Music Creation
}

\author{
Aton Rustandi Mulyana ${ }^{\mathrm{a}, 1^{*}}$, Joko Suranto ${ }^{\mathrm{b}, 2}$ \\ ${ }^{a}$ Institut Seni Indonesia Surakarta, JL. Ki Hajar Dewantara No. 19, Jebres, Surakarta 57126 Indonesia \\ b Universitas Sebelas Maret, Jalan Ir. Sutami 36, Kentingan, Jebres, Surakarta, 57126, Indonesia \\ ${ }^{1}$ atonrustandi@gmail.com*; ${ }^{2}$ jokosuranto@staff.uns.ac.id \\ * corresponding author
}

Article history

Received 2020-12-17

Revised 2021-05-28

Accepted 2021-06-20

Keywords

Al Suwardi,

Nunggak Semi

gamelan Genta

Planet Harmonic
This article examines the artistry of a composer named Aloysius Suwardi. This composer, who grew up in the Javanese gamelan music tradition, has produced musical compositions and created musical instruments as a means/medium to express it on the journey of his creativity. His works have been staged in various forums or world music festivals. The musical instruments he has created fill the laboratory spaces to create his musical compositions. Two musical ensembles that have been created are Gamelan Genta and Gamelan Planet Harmonic. These two musical instruments complement the many personal musical instruments he has created, such as the vibrander, tering, gerendang, and other musical instruments. Regarding the two ensembles, this article examines the aspects of the creation process. For example, how did Al Suwardi choose the materials used, how to make them, to how he determined the barrel system for these tools. In terms of compositing, this article examines how Al Suwardi started his work, his models of creation, and how he composes his works until they are declared final. The gragas and dridis creeds and Nunggak Semi's concept are the main topics in this composition creation model. Both creeds and concepts have ushered in the landscape of making Al Suwardi's musical compositions expand, from the gamelan tradition to more contemporary models of music creation.

This is an open-access article under the CC-BY-SA license.

\section{Introduction}

Aloysius Suwardi, who is more familiarly called Al Suwardi, is a writer, academician, composer, gamelan tuner, and innovator in creating new musical instruments that since the 80 s has been active in the Javanese karawitan-based area of art (music). His work, actions, and traces of his work have given a new color to Indonesia's cultural treasures, especially in the realm of music. As a composer, Al Suwardi gave birth to new musical works and introduced new instruments resulting from his explorations. In addition, Al Suwardi was directly involved in selecting materials, production (manufacturing), aligning, and presenting his work for the new creation process. He has received many awards from within and outside the country for the process and work he has produced so far. Al Suwardi's background, raised by the Javanese karawitan tradition, encouraged him to do creativity and innovation. The Javanese karawitan treasury did not stagnate and stop as 'the past' but was sensitive and adaptive to modernity development. The works produced by Al Suwardi are in line with what is echoed by the government through Law No.5 of 2017 concerning Cultural Advancement. The advancement of culture is structured based on practice and thought based on realities that already reside in society. Spirit, innovation, and creativity Al Suwardi have carried out the concept of cultural preservation and cultural development because it considers the current era's character. Seeing the considerations that have been conveyed earlier, the efforts to track, document, compile, and transfer 
Al Suwardi's knowledge in the field of artistic work that he has done is essential and urgent. All of these efforts have an evident urgency, namely to ensure that the knowledge and values/spirit of $\mathrm{Al}$ Suwardi that are summarized in all of his works do not become something exclusive because there is no effort to document, systematize, and socialize.

Studying the composer Al Suwardi is not new; many researchers discuss the creation of $\mathrm{Al}$ Suwardi's music. However, their research does not reveal how Al Suwardi made new musical instruments and how organological techniques were arranged. Moreover, no one has even mentioned Al Suwardi in promoting music culture within the framework of implementing Law No. 5 of 2017 concerning the Promotion of Culture of the Republic of Indonesia. Warde briefly mentioned the study of the creation of music by Al Suwardi. The work observed is a composition entitled "Debah." Warde investigates how Al Suwardi uses the concept of experimentation and how the method contrasts with some aspects of the American and European experimental music movement. Warde also considers several methods by which the central concepts of traditional Javanese gamelan music have been changed and emphasized during these musical experiments [1]. His seniors also influence $\mathrm{Al}$ Suwardi's musical ability, which can be seen from Rahayu Supanggah's statement involving Al Suwardi in his works. In the creative process, Rahayu Supanggah always works together, and they always start with an idea, and that idea is developed when they practice together [2]. A. L. Suwardi's contribution to music creation can also be seen from "Sindhen Kewek," a work reviewed by Spiller. According to him, A. L. Suwardi is trying to "revive" siteran (music played with plucked kecapi that usually imitates the texture of gamelan) [3]. Another experience of Al Suwardi is being involved in determining the specifications of the Digul gamelan, starting from the instrument, barrel, construction, materials, playing style, and conservation. In addition, he was involved in the preservation of the gamelan and did the tuning for each instrument [4], [5]. Al Suwardi, together with Gamelan Madu Sari, have also held a one-month residency to train new traditional works and collaborate in the creation of new works. This interaction is an essential catalyst for making new music. According to Miller, the collaboration with Al Suwardi is equally inspiring as a model for collective creation. The process consists of several rehearsals in which the musician improvises, freely exploring the instrument's sonic potential at hand. Al Suwardi then organizes the material that has been produced collectively, making a map of music players [6].

This article aims to ensure that the richness of artists' works is documented. These works can always be conveyed from generation to generation to anticipate the threat of dimming the traditional treasures by the increasingly unstoppable wave of modernity. This article is a form of documentation of the knowledge and skills of Al Suwardi's work as a music composer, gamelan tuner, and creator and innovator of the creation of new musical instruments. Through this text, the inheritance of cultural values and local wisdom through Al Suwardi's works can be read by a wider audience. On an impressive scale applicatively, artists such as Al Suwardi can be applied and transformed into life in today's society and the future.

\section{Method}

To find out Al Suwardi, both as a composer, tuner, and creator of new musical instruments, the writer uses investigative journalistic methods to explore it [7]. This method is more akin to ethnographic work, but with an intense, in-depth interview and a sharp observation of musical instruments' work and musical compositions created by $\mathrm{Al}$ Suwardi. The author also adds several related references in articles and research reports on Al Suwardi's work and Al Suwardi's thought profile and history to strengthen the analytical arguments for this journalistic work. For example, as the results of research by Bambang Sunarto [8], [9], McGraw [10], Sadra [11], Perlman [12], Hoskin [13]. The author also uses discussion forums and workshops about Al Suwardi's work as reinforcing information. Several testimonies from colleagues and music observers were also presented as speakers. Resource persons' testimonies are significant for the discussion of Al Suwardi's work and creative process. After determining the method above, the author examines the core issues which are the subject of this discussion, namely (1) regarding the organology of the musical instruments created, especially the Gamelan Genta and Gamelan Planet Harmonic instruments. (2) The creation models are used to depart from the Nggragas and Ndridis creeds and the concept of Nunggak Semi. Finally, to refine the analysis, the authors relate it to references according to the predetermined method. 


\section{Results and Discussion}

\subsection{Gamelan Planet Harmonics and Genta}

\section{1) Planet Harmonic Gamelan}

Al Suwardi deserves to be placed as a complete music maestro. He is a karawitan artist with many unique competencies in the world he is involved in: A composer and a musical instrument maker, tuner, and ethnomusicologist who teaches at the Karawitan Department Postgraduate Program the Institut Seni Indonesia (ISI) Surakarta. Thus one of the musical instruments created by Al Suwardi, the Gamelan Planet Harmonics, is a vital signature between the moments he has created for his musical instruments. This gamelan brings the landscape of the creation of Al Suwardi's musical compositions to a richer and more colorful way, technically, methods, procedures, and approaches or his work's perspective. Al Suwardi shared his experience in creating this musical instrument. He mentioned that the process of making Gamelan Planet Harmonics began in 2008. Until now, this gamelan is more complete with the addition of other musical instruments, and this can be seen in Figure 1.

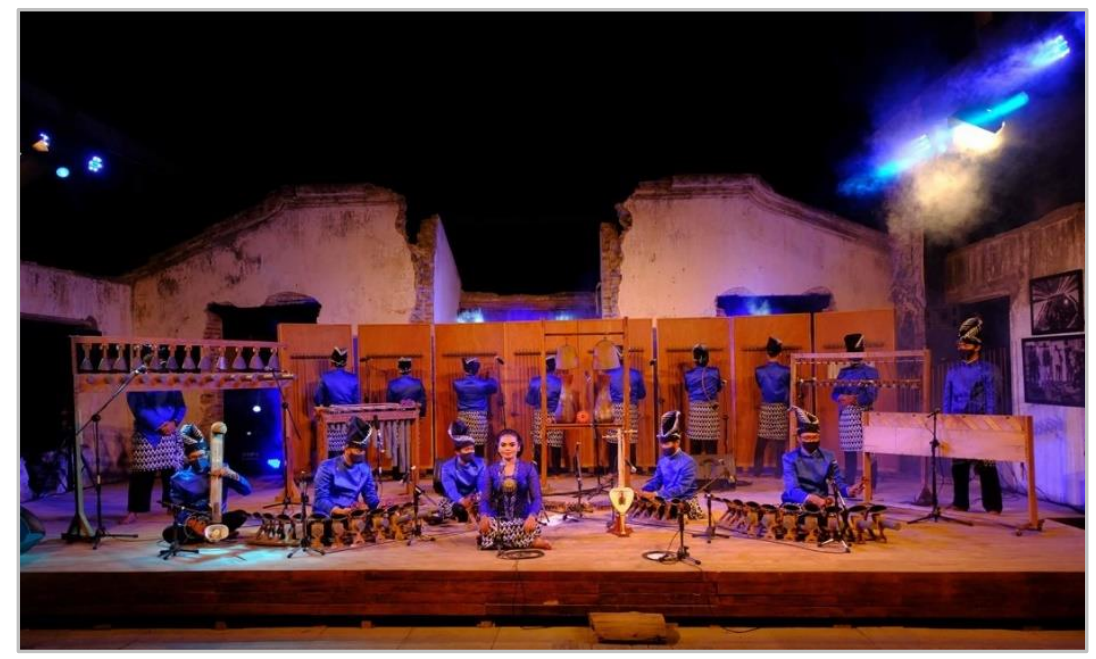

Fig. 1. The Diversity of Musical Instruments Planet Harmonic Gamelan, Photo Source by Danang

Harmonic planets are selected based on their sound source, where the sound source is chosen as an iron rod. The round section of the iron rod with a diameter can be selected according to the desired sound character. For Al Suwardi, this instrument is crucial because it is a means of expression for an artist. Indeed, there are gamelan and other musical instruments that artists can use, but for him, the use of these musical instruments must be by the intended use. "I made this new musical instrument for reasons. Why? Because in composing music, I have difficulty getting the sound color I want, "said Al Suwardi, adding that if the sound you are looking for or what you want is not found, then there is no other way except to produce an instrument or look for the sound through the instrument created. Of course, the search process does not just come but through a long process. In general, Al Suwardi said that the basic principle of making musical instruments is the material and shape, and the resonator aids as sound producers. The material used in the manufacture of the Harmonic Planetary Gamelan, as mentioned earlier, is iron with a round cross-section; in this case, a diameter of $6 \mathrm{~mm}$ is chosen. The iron $6 \mathrm{~mm}$ in diameter is cut into the desired tone. Next, he will make other pieces of various sizes that have been determined in diameter or length. There are $6 \mathrm{~mm}$ and $8 \mathrm{~mm}$ cross-sections, and there are even $4 \times 4 \mathrm{~cm}$ iron blocks selected for the making of the gerendang-type gamelan. Length is about $75 \mathrm{~cm}$ or less than 1 meter. There are screw nails, plywood, and wooden boards to make frames in this gerendang-type musical instrument. This instrument also has a wheel that can be pushed when moving the instrument. He prepares many mechanical types of equipment such as drilling machines, grindstones, saw, and other woodworking tools. He also always prepares work safety attributes, such as wearing masks, earplugs, and gloves for hand protection. Al Suwardi determines the material for a particular tone according to the desired tone sequence. The form of this gamelan has a part that is designed like the shape of the waist, which is a part of the rod that is flattened $10 \mathrm{~cm}$ from the end of the iron. The pieces of iron were flattened 1 to $2 \mathrm{~mm}$ deep or $2 \mathrm{~mm}$ to $2.5 \mathrm{~mm}$. The thickness of the flaked iron affects the strength of the iron and the duration of its vibration. The thicker, the resulting sound vibrations are not that long. Sebailknya will vibrate long if the iron is flattened up to $2 \mathrm{~mm}$. 
However, the risk is that if you play it continuously and for a long time, the tool will break easily. He called it part of the experimental process. Even today, Al Suwardi is still looking for more durable and not easily broken materials. "Right now, I have not been able to find a perfect material but have been able to come up with the sound idea I imagined," he said while giving a workshop in front of the musicians virtually. Creating a plan is another side that cannot be separated from the Gamelan Planet Harmonics' existence. Bakan, according to Al Suwardi, can contribute to sound production. The design can be a resonator of a sound source. Making design requires reliable and heavy material because it is to withstand vibrations. On the other hand, in order for the sound to be louder, vibrations must be transmitted in a plane to travel in all directions. The field vibrates the surrounding molecules, making the sound that appears even more vital. Thus the resonator performs its function to amplify the sound source.

\section{2) Gamelan Genta}

Gamelan Planet Harmonic, apart from being a unique piece of craft made of iron, when played, there is also a Gamelan Genta that Al Suwardi has created. Al Suwardi stated that Gamelan Genta was made based on his teacher's story, namely Mloyowidodo. Mloyowidodo mentioned that the Keraton Surakarta once had a gamelan gift from Raja Thailand. Related to this, we can also read Hughes' research [14]. Gamelan Genta, in general, shape resembles the Kepoh fruit's skin or is similar to a Mahogany fruit, which resembles two clasped palms. If the Mahogany fruit is broken, not all skin is destroyed but only splits into two parts. From the description, such as the fruit's shape, Al Suwardi then imagined and developed it by observing cowbells often worn around the neck of cows; see Figure 2. Al Suwardi had wanted to trace it to the palace, but he said the gamelan had disappeared. "Instead of looking for nothing to find, I better make it like the image told by Pak Mloyowidodo," he related.

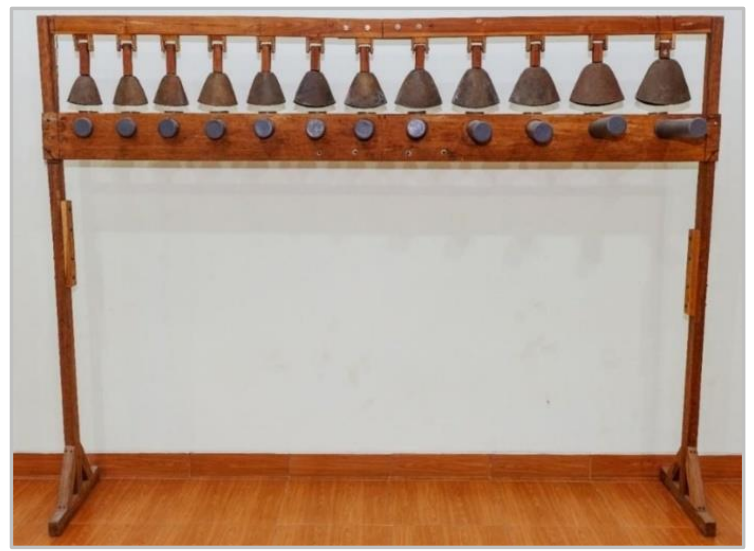

Fig. 2. Gamelan Genta is made of cowbells which are often worn around the neck of cows

Then, Al Suwardi also made a musical instrument that looks like a cow grocery. The first time a Gamelan Genta was made (Figure 3), it was small because it used a thin metal. He then developed it by using iron as a turn so that when it touched the bell's body, the sound was jingling more. He then imagined playing it and found the way, which shook it like playing angklung music. Next, Al Suwardi made many bells to form a sequence of notes in one plan. Then, he chanted on the Slendro scale.

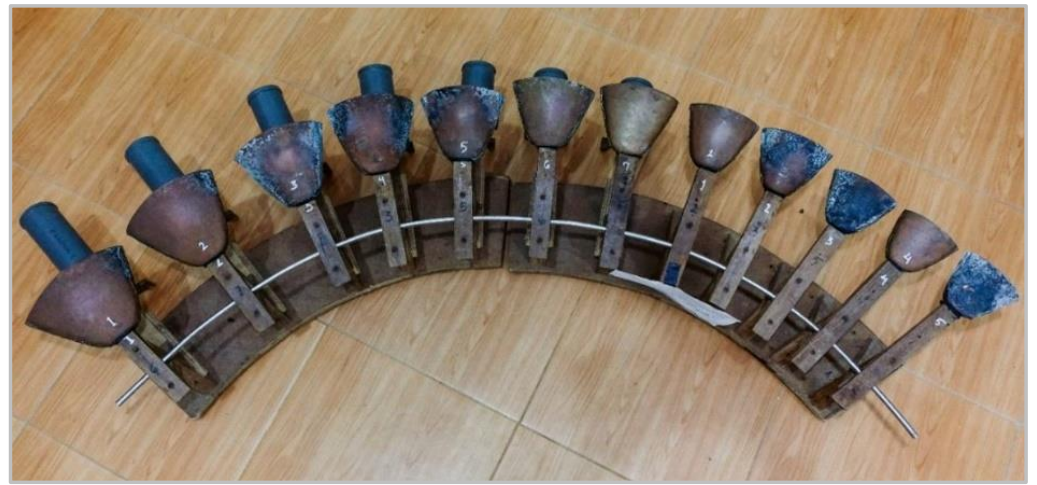

Fig. 3. Gamelan Genta which is played by shaking it with a slendro scale 
Al Suwardi also developed the production in many sizes and ways of playing it, so that he formed a large bell, hanging, with the technique of being hit. The large, hanging Gamelan Genta is called Klonthong; look at Figure 4. Klonthang produces sound reflections from the resonator, which periodically sound the strength of the sound. He also thought of the ricikan, which played the melody's role, and the realization of Klonthang, which did not shake when hit quickly and produced a clear sound. Then, the bell whose tone size is one octave below Klonthang, namely Klunthung. If ordered, the Genta with the low tone region is Klonthong, the medium in the Klunthung region, and the highpitched one is Klonthang.

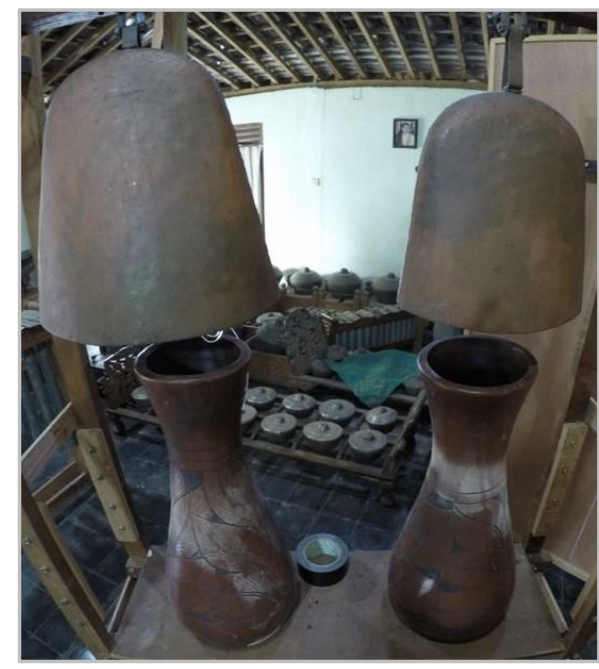

Fig. 4. Klonthong, a large hanging Gamelan Genta

\subsection{Nunggak Semi Al Suwardi}

From the perspective of creativity, karawitan can create new works as a form of sustainability from traditional forms and rules. However, there are not many new karawitan works that can be felt new [15]. In the music composition, many essential things are interesting to study in connection with the creative process. The compositional process in music is primarily determined by the composer's cognitive competence and technical abilities. Bambang Sunarto said art is about artistic values and systems arranged and expressed according to the creator's beliefs, choices, and works [8]. Thus, in terms of music, music composition is a product of the composer's creativity in work, manifested through generative powers in the form of intellectual thinking and the artist's technical-praxis abilities. Apart from that, sensitivity in reading forward projections is another skill that brilliant composers should have. A work (music) will not be made for itself but presented to other parties or a specific audience. Here, the composer and the audience will build a reciprocal relationship on the message conveyed, affecting the subsequent work's plans. The relationship between composer and audience can be examined in Schütz's research [16]. There are things where the composer first looks at the experiences contained in it and sees how the audience can enjoy this work. Communication of taste is vital, including in the side of the message to be conveyed. What messages to convey becomes the basis for how the composer mixes the composition. Al Suwardi has the basic principles of making compositions and a very personal arrangement model regarding all of the above.

In composing music, Al Suwardi conveyed an analogy by telling a story when he was abroad. It said there was no rice, only potatoes and fried chicken. At first, he did not want to eat because he was not used to it. Finally, however, he forced himself. Moreover, he felt that the french fries were delicious. He was also invited to eat cheese, which was very far from his tongue's taste, namely Java's tongue, but it was delicious when he tasted the tars. From that experience, Al Suwardi believed that food was not just food that was usually eaten before. Any food can be enjoyed by practicing continuously so that the tongue can feel the difference between one food and another over time. "Living with music is also like that," said Al Suwardi. In the past, for him, if you did not listen to the gamelan, the other gamelan was not music. Never mind the non-music. His fellow gamelan was not as easy as enjoying it. Listening to Balinese gamelan at that time, it was as if he only heard the krompyang krompyang sound and could not feel it at all. However, because Balinese gamelan was one of the subjects he had to take while studying at ASKI Surakarta, he was forced to practice. As a 
result, he was always addicted to playing Balinese gamelan. According to Al Suwardi, this beauty can be seen from various angles. Appreciation of unusual food to eat, including whether the roar of a machine is beautiful to enjoy, can be used as a musical composition material. So, music is not only beautiful. In crude Javanese, Al Suwardi calls it nggragas, which is the behavior of frequently trying foods that have never been tested before. From the variety of food he tasted and various music forms, he enjoyed enriched perspectives in music. This can be a capital before the composer makes music. Like when he was traveling alone and had to cook by himself. He tries to cook with an existing recipe, but he also tries to cook it without a recipe that produces its taste, which is very personal. The experience of eating or experiencing some music stimulates Al Suwardi to try and keep trying. Ndridis, in Javanese. This is an action driven by a great deal of curiosity (curiosity). Someone who has much curiosity will keep trying and trying and trying. This led him to carry out unusual experiments. Apart from nggragas and ndridis, he advised artists always to have an adventure. "There are challenges in adventure," said Al Suwardi.

Moreover, according to him, the artist must continue the adventure. These three things encourage him to work and compose music. These three principles are the basis for Al Suwardi to work, not to theorize. Because according to him, the basic principle for composition does not exist. All composers have their principles. Every composer has different beliefs. So, if someone makes a composition according to theory, it is considered a delay, not to mention ignorance. The theory is produced from experience. The composer takes action first, then develops a theory. "If you want to become a successful composer, do not use theory but use your own beliefs," he said. However, in an academic context, he reminded three things that need to be considered in making music: (1) the student expects an aesthetic thing, (2) academic demands (3) ethical demands. These three things are used as reference/assessment criteria on campus. As for the organic ones outside the campus, what is believed to be the way of creation is a choice made by the composer. Even, he also considers the context of the show, which should be empang papan. — music for what, where, who the audience is, things that must be considered contextually. Do not let the performance happen; they will be considered insulting certain cultures because they do not see the show's context. On the other hand, if there is a need to be done, it may give birth to revolutionary work. The most striking break-ins and moral fights are Al Suwardi's favorite music. For example, the idea is to mix Sundanese, Javanese, and Balinese musical souls. For this work concept, Al Suwardi wants to mix it up; for example, in the gending section, there is a merong; and there is an inggah. In the merong section, he can fill it with Sundanese works; there are also Balinese works. After that, he explored what wasp patterns and the sounds of the instruments used were then compiled.

A relationship between one instrument and another or the form of play for each instrument had to be played the same or made different. His pengrawit has provided a notation arrangement with detailed instrument parts. Everything is tried in the training process, and it is all recorded. After the practice is over, the recordings are listened to and evaluated. If there is a revision possible, revise it immediately, then train again. Sometimes revisions occur during practice. After revision, then finalization and considered as a complete composition. So, if the parts of Al Suwardi's creation process are listed, they are (1) idea, (2) concept, (3) exploration, (4) conceptual arrangement, (5) training, (6) evaluationrevision, (7) finalization. The creation model is in compositions that outline melodies and rhythms from exploring ideas to form forms. Is it in the form of a vertical-horizontal relationship or in the form of melody development itself? After that, the next step is to develop each section. The relationship between these parts is necessary to do a particular practice as a bridge or take part while considering its dynamics. Sometimes, melodic play dynamics occur during rehearsals or are thought of before practice: whether they are loud or played weakly. The process continues until everything is ready and the supporters of the work (pengrawit) feel confident to play in a relaxed and comfortable manner. At this point, the composers do not just play the part but also feel the "spirit." In any model of creation, Al Suwardi constantly explores ideas, ideas and executes his work. It could also be that the process or procedure itself is shown in the show. There is the effect of seeing how many other composers have carried out these kinds of processes. Al Suwardi admitted that he had done it during the Young Composers Week in Jakarta in the early 1980s, where he presented the composition-making process in his performance. For Al Suwardi, every composer must have his way of creating his work. Moreover, he said the model he did to create his musical compositions was Nunggak Semi. Other models he uses are Gineman and Bisumsum. Al Suwardi admitted that he was only limited to the three models. If the schema is created, procedure I for the Nungga Semi model is is shown in Figure 5. The explanations are (1) Idea, exploration of idea achievement. The form is a composition that describes 
the melody and rhythm. Shape development can be either vertical or horizontal; (2) Part-by-part development; (3) Partial relationship, namely whether there is a need for a bridge or a direct relationship; (4) Adjusting the dynamics, thinking before composing a melody or during the rehearsal; (5) Notation process; (6) The training process until it is ready to be presented to the public.

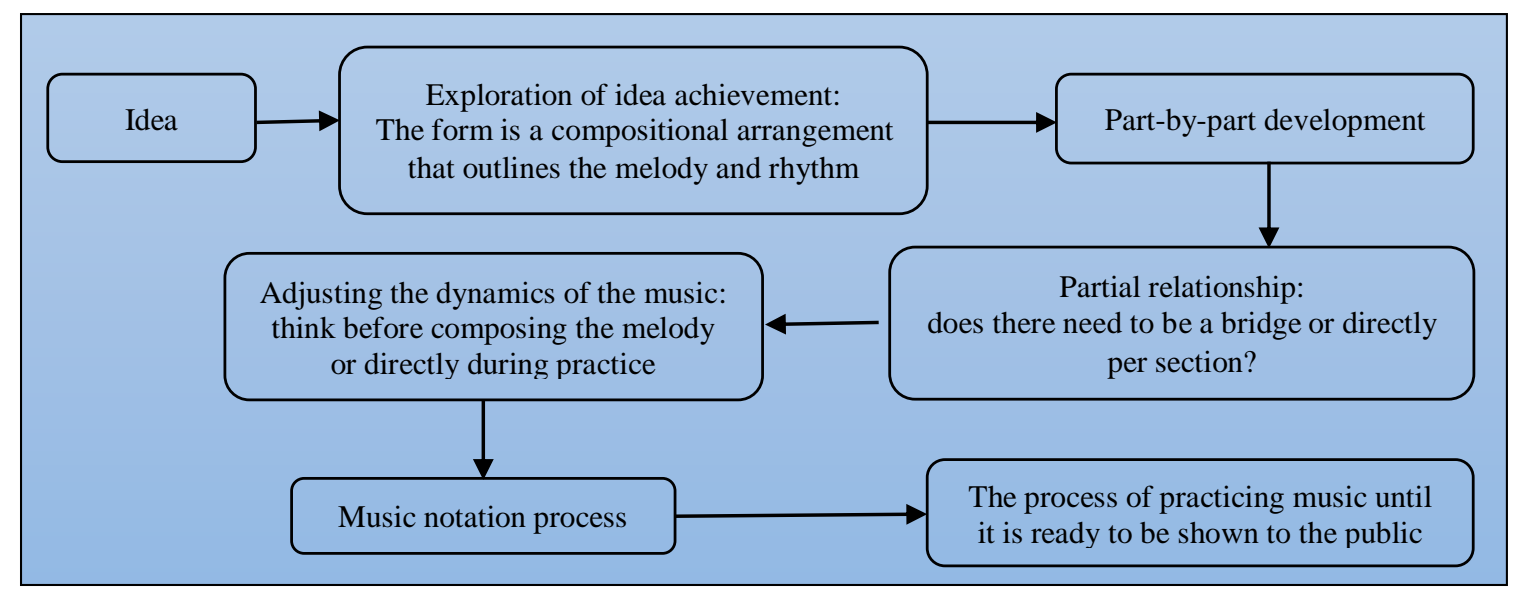

Fig. 5. Procedure I of the Nunggak Semi model

For Al Suwardi, musical composition is like when he wants to cook food: using various kinds of mixed spices, and then the results are felt. This is called the second procedure in the creation of a musical composition. Here, making a musical composition can be started by exploring using specific musical instruments. Try to explore this tool: produce any sound; how or how to sound the technique, whether it is beaten with a specific tool, picked, hit, or rubbed, and so on. Exploration is carried out until it finds something meaningful for the composer. Al Suwardi reminded that this exploration process must be remembered, and so that it is not lost from memory, it must be recorded or, better yet, recorded. Then, the results of the recording are listened to again. Exploration activities are carried out repeatedly to get a lot of sound deposits (banks). Composers, thus, have many options to suit their needs. The composer then formulates the concept of his compositor and designs an arrangement of materials by the concept. The materials are selected, selected, and then arranged to meet the drafting concepts. In the process of searching for this sound, it can be done independently or with fellow pengrawit. For example, in expanding the development of a playing technique, Al Suwardi played with some of the techniques he mastered, then tried them together. So the exploration for him may be accessible according to the composer's wishes. After exploitation, it was then processing flow and dynamics. In his experience, sometimes what has been arranged according to the concept, after being trained together, does not match what the composer imagined. If it does not fit, adjusted, or moved, it is more suitable according to the composer's belief. Sometimes when you think about dynamics, you process the dynamics. However, if a composition does not require dynamics, wants it to be straight, yes, not processing dynamics is also okay. If the procedure for Nungga Semi II is formulated, it can be seen in Figure 6. the explanations are as follows, (1) Do not have an idea, starting from sound exploration; (2) The voice search process can be independent, accommodated, recorded, trained together; (3) All search results are accommodated to produce a good data bank; (4) The collected voice data are arranged to form an organized sound structure; (5) Processing flow and dynamics.

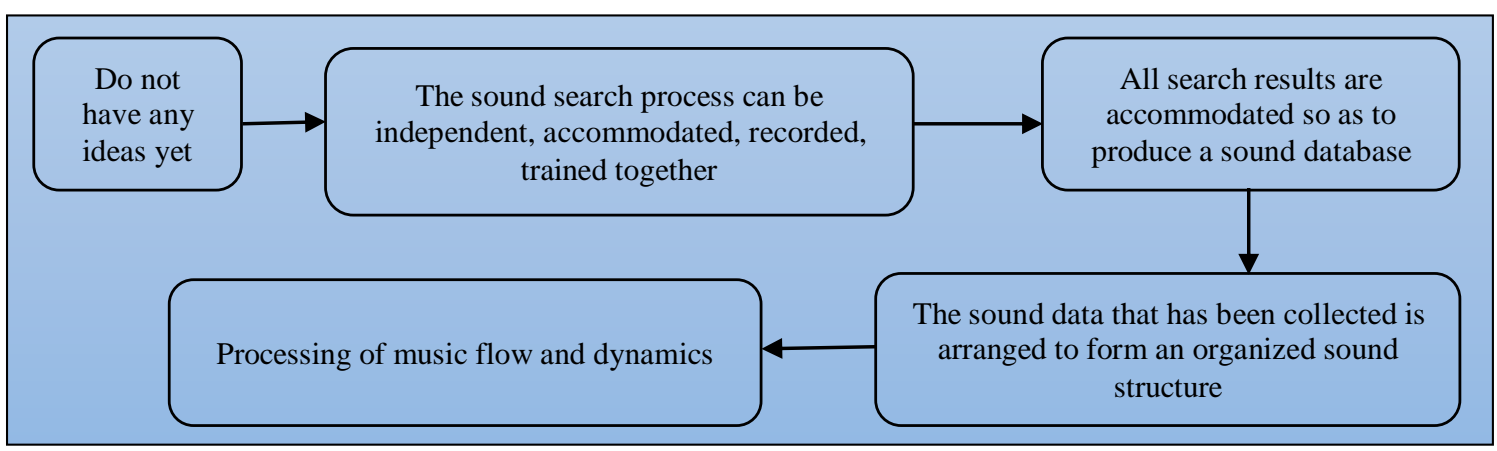

Fig. 6. Procedure II of the Nunggak Semi model 


\subsection{Al Suwardi's Discourse on Music Creation}

The analogy of composing the composition with the cooking food process by Al Suwardi shows the perspective of creating a very personal composer. In this context, Al Suwardi has indirectly emphasized the importance of a creed that a composer must own. This is very important to give confidence in his musical attitude. Nggragas and ndridis, as Al Suwardi's musical credo, have shown how to behave by describing personal experiences experienced. The first is nggragas, which means there is no need to be afraid, no matter what kind of food you try, because later, the body will select which ones it does not like. Second, ndridis, which leads to an exploratory, experimental, try, try, and try, is based on the nature of curiosity in each human being, child or adult. This is a gift because it must be optimized for creative people. Apart from the two creeds above, what should also be noted is that Al Suwardi's relentless search has demonstrated his duty as a composer who thinks about past experiences but then projects them forward. Because of this, a composer cannot necessarily refer to theory because his body is prophetic: it presents itself for the future. Not the ability to learn from memorization, skills, but a trained body because the composer had to think ahead. Al Suwardi's model of creation shows that the composer's intuition can have forward dimensions. Maybe it is not realized, but maybe it is also his creative anxiety that always disturbs and always makes Al Suwardi always take exploratory actions.

In Planet Harmoni, Al Suwardi is very much based on a mature idea, which is revealed to be a concept, and from the concept then explored, arranged in parts, then tried first and later, if you find what you are looking for, then train with pengrawit who support his work. Even in training, there are still many possibilities that can change the composition or other changes until the evaluation process, which results in a work that is considered final. This reminds me of composer I Wayan Sadra's musical credo, free music from its cultural burden. This creed contains the spirit so that composers are not burdened with what they want to present to their music. This is by the exploratory model conducted by Al Suwardi. Thus AL Suwardi has given an example of how a composition begins to how it ends. The models, perspectives, and musical attitudes remind Javanese gamelan musicians to be accustomed to the multi-layer principle. Al Suwardi, as a pengrawit, in his heart, is very familiar with the understanding of gamelan's musical pathways, which are very complex and have many paths. For Ade Rudiana, a lecturer from the Indonesian Institute of Arts and Culture (ISBI), Bandung, apart from extensive theoretical capacity and musical experience, also requires delinquencies that are sometimes "extraordinary" in nature.

Ade saw the "mischief" in Al Suwardi. As a former student during his study at the Indonesian Eni High School (STSI) Surakarta - now ISI Surakarta - Ade understood very well how Al Suwardi's mischief at that time had led to creativity in making qualified compositions. This creative mischief further strengthens that creating musical creativity does not just happen. Not "Sim Salabim" like in a magic game. However, it further strengthens that a composer should also have other knowledge. Moreover, the composer is in the academic zone. For Ade, what Al Suwardi has done further reinforces that music is also based not only on madness and anxiety but also on the intelligence that manifests in Al Suwardi. Even though he has traveled everywhere, he, born in Java, has not lost his Javanese personality. Also, the living and understanding of musical influences from various cultures and ethnicities is an asset that further enriches his referential power - the richness of experiences and references that reflectively become a personal power that every artist should exist. This allows each artist to have his way beyond the knowledge obtained from other sources. At that point, the artist has his device, prepares a model, and practices personal creativity. At that point, Al Suwardi always advised his students to use their way to get out of other artists' creativity shackles. Because, as recommended by $\mathrm{Al} \mathrm{Suwardi,} \mathrm{make} \mathrm{this} \mathrm{body} \mathrm{a} \mathrm{place} \mathrm{to} \mathrm{input} \mathrm{knowledge} \mathrm{or} \mathrm{other} \mathrm{knowledge} \mathrm{obtained}$ anywhere. He emphasized that to make a creative and innovative work requires an element of novelty. Discoveries, whether in form or practice, are markers of the composer's creativity.

Al Suwardi said that currently, there had been several composers who have jumped from an aesthetic perspective. In a sense, what is worked on is not an aesthetic aspect but rather an intellectual experience. They make music, but you cannot find it there with musical glasses if you live it musically. Because what they are exploring is their intellectual experiences, as did Alvin Lucier. Lucier's work entitled I am Sitting in The Room is a recording repetition project, in which a recording is played, then re-recorded several times [17]. In the umpteenth generation of recordings, I am Sitting in The Room was not heard from again. For Al Suwardi, if it is lived aesthetically, the music is sometimes 
not met. What is explored is how from generation to generation, an idea is formed and influences the echo of the room's sound in a recording. So what he is saying is the echo and generation of the tape. If you live a musical aesthetic, you may not find it. What is beautiful is how it changes from the tape. So the glasses are completely different. According to Al Suwardi, Alvin Lucier's model could happen because he wanted to be creative and ndridil! Without going through these two things, the composition cannot be richer in taste.

Moreover, this is for the exquisite taste and new experiences or sensations that were not possessed by previous musical compositions. Al Suwardi, an academic and ethnomusicologist, has done intense research to create every piece of music. He can even connect an academic study and practical creation into his work approach model is. According to Al Suwardi, there are different ways or characteristics of work between people's needs to create works of art and people who study them - although, on the other hand, there are some similarities. In essence, searching is the same; wanting to find something new is the same. However, how to cultivate it, manifest it, and express it are different. Only, when it comes to artwork, the ability to predict it is more important. It is conveying something upfront like never thought before. The Harmonic Planet Gamelan is an example. When there is a very long century trajectory - in which Al Suwardi reads it - it turns out that it happened in a very long century, long before we were born. However, in the end, they were able to, say, bring it back with imagination as if the gamelan had already represented it. If based on written text, the nuance of absence may not be caught. However, with the ability, experience, sharpness, intuition, and sensibility of Al Suwardi's body, the past experiences seemed to come back.

In other words, the Planet Harmonic Gamelan seems to bridge things that may be inconceivable into imaginable. Audiences can feel the sensation of the harmonic sphere, and the harmonic series is now confirmed. It is no longer just a written statement, but the fact is there. In Ade Rudiana's language, Planet Harmonic proves that Mr. Al Suwardi's work is scientific and argumentative! Affirming Al Suwardi's work's scientific aspects, Diah Latifah, a lecturer from the Indonesian University of Education (UPI) Bandung, stated that the method for arranging Planet Harmonic is obvious. His ideas, his ideas are also evident. It can even be said that this composition includes polyphony, not polyrhythmic music. Each plot of Planet Harmonic has its meaning. This was confirmed by Al Suwardi, where the melodies he constructed compose various kinds of melodies. However, all of them have a relationship. Every melody sometimes means nothing if it stands alone. Conversely, one melody can be developed with other instruments to support each other and give each other meaning. "I am still complete with traditions, and it (Planet Harmonic) is indeed thick with tradition, and I still play traditional works," admitted Al Suwardi.

Al Suwardi further explained that the work of a melody initiated the Harmonic Planet's composition. The Harmonic Planets filled songs based on the melody made by the Gamelan Genta. The melody of the song is synchronized, sometimes using a gender-beat pattern. In making a melody, it is not taken for granted but is mixed in such a way. The rhythm can depart from the same insignificant idea as a musical melody, but other melodies are built and lead to the same tone, with a different type of rhythm. Al Suwardi admitted using the pelog gamelan interval because Planet Harmonic Gamelan is made in the pelog gamelan's tuning. He has made the gamelan hilt master, and that master is used as the parent of the Planet Harmonic Gamelan. So it is clear that what Al Suwardi presented in Planet Harmonic comes from traditional music. This was referred to as reflective, which presented a very personal behavior and perspective of creation. Here is also the essence of $\mathrm{Al}$ Suwardi's Nunggak Semi approach. Rustopo said Nunggak Semi is a development concept known to the Javanese. This term describes the planting of plants from stumps or the remaining parts of old plants. This is like a change process that produces innovation but grows from old scraps [18]. For Misbach Daeng Bilok, a musician from Selayar, South Sulawesi, Al Suwardi increasingly encourages the belief that a composer will be much more confident when he starts playing music that he creates himself. A composer is also more motivated to work when he can release music from his cultural burden.

Moreover, a composer also dares to explore when he sees how his ancestors' sound culture, which is not yet said to be music, is present on various islands from Sabang to Merauke. All of them are placed respectfully in their cultural life. In the Planet Harmonic Gamelan, the oval iron's crosssections as the gamelan material are reminiscent of Misbach's ancient wall clock. He also suspects that such things inspired Planet Harmonic's Gamelan. In form, Al Suwardi accepts the similarity of the gamelan to ancient wall clocks. However, the sound and shape of Planet Harmonic's Gamelan is 
purely his invention. What is the shape, how to realize the sound to reach a long vibration duration? This sound quality is clear but has a clear harmonic tone series, and all are the results of experiments and explorations conducted by $\mathrm{Al} \mathrm{Suwardi.} \mathrm{Al} \mathrm{Suwardi} \mathrm{also} \mathrm{felt} \mathrm{that} \mathrm{after} \mathrm{listening} \mathrm{to} \mathrm{the} \mathrm{clock} \mathrm{on} \mathrm{the}$ wall, he found a similarity. However, the character and color of the sound he presented he found through long and intense experimentation. "I started sticking metal rods into the wood; I once also stuck them into castings; after the cement was dry, I beat them. So the sound can be, but it still does not produce a loud sound either. After that, do the making of flattening the part that forms a waist so that the sound is like what has been finished. So it is not inspired by wall clocks, but there are similarities after it was finished, so coincidentally, it is the same. " Al Suwardi described the manufacturing process.

\section{Conclusion}

For more than half a century, Al Suwardi has been in the world of music, especially Javanese Karawitan, which is quite a long time for anyone who dedicates his life to his field of interest. However, a long period becomes meaningless if it is not filled with achievements. Al Suwardi has put several "markers" that have become essential milestones in music's life. There is a longing for the presence of a music maestro in this millennial century. Apart from not many musicians who have maestro capacity, there is not much communication to the public. Al Suwardi spread role models in responding to music and role models in the artistic association. He has great respect for the generation of musicians under him. He gave it all, devoted all of it, for the sake of enriching music and gamelan in particular. He is a composer who happily describes how the new musical instruments were presented and how the instruments are tuned, including how these instruments can be finally used to make musical compositions. Al Suwardi had high hopes for an elegant inheritance process for the works he had carved in a discussion. He wants Gamelan Genta, as well as Planet Harmonic, to continue or develop it. He volunteered to help with his inheritance activities. He also thought again about the gamelan Genta's tracking, which had vanished due to the desire to immediately make the imitation of the gamelan more "burning" before the research was carried out. What was the original form or form, what kind of repertoire was played, were questions that bothered him? Its mission is to interpret Gamelan Genta in its new Gamelan Genta form, with new musical compositions not so that the gamelan can come back to life. However, the effort to conduct research and trace the gamelan's existence is also a stored desire that still wants to be realized.

\section{References}

[1] A. Warde, "Contemporary Indonesian Composition: Elastic-Edged Experimentalism," Asian Music, vol. 34, no. 1, pp. 111-153, 2002. Available at: Google Scholar.

[2] B. Benary et al., "Notes on the Compositions," Leonardo Music J., vol. 2, no. 1, p. 103, 1992, doi: 10.2307/1513217.

[3] H. Spiller, "Gamelan of Java: Volume One, Kraton Kasunanan.” JSTOR, 2011. Available at: Google Scholar.

[4] S. Williams, "The Gamelan Digul and the Prison Camp Musician Who Built It (review)," Notes, vol. 59, no. 3, pp. 622-623, 2003, doi: 10.1353/not.2003.0044.

[5] N. Gray, "The Gamelan Digul and the Prison-Camp Musician Who Build it: an Australian link with the Indonesian Revolution.” JSTOR, 2003. Available at: jstor.org.

[6] C. J. Miller, "Orchids (and other difficult flowers) revisited: A reflection on composing for Gamelan in North America," World Music, vol. 47, no. 3, pp. 81-111, 2005. Available at: Google Scholar.

[7] D. H. Weaver and M. E. McCombs, "Journalism and Social Science: A New Relationship?," Public Opin. $Q$. , vol. 44, no. 4, Polls and the News Media: A Symposium, p. 477, 1980, doi: 10.1086/268618.

[8] B. Sunarto, "Model and Concept in the Music Paradigm of Creativity," Music Scholarsh. / Probl. Muzykal'noj Nauk., no. 3, pp. 103-113, Sep. 2020, doi: 10.33779/2587-6341.2020.3.103-113.

[9] B. Sunarto, "Musical Genres in Music of Karawitan Crosswords Between Tradition and New Music," Sineris Rev. Music., no. 21, pp. 1-23, 2015. Available at: Google Scholar. 
[10] A. C. McGraw, "Radical tradition: Balinese musik kontemporer," Ethnomusicology, vol. 53, no. 1, pp. 115-141, 2009. Available at: Google Scholar.

[11] I. W. Sadra, J. Diamond, A. Solehuddin, and T. Rohlck, “'Komposisi Baru': On Contemporary Composition in Indonesia,” Leonardo Music J., vol. 1, no. 1, p. 19, 1991, doi: 10.2307/1513116.

[12] M. Perlman, "The Traditional Javanese Performing Arts in the Twilight of the New Order: Two Letters from Solo," Indonesia, vol. 68, p. 1, Oct. 1999, doi: 10.2307/3351295.

[13] J. Hoskin, “Central Javanese court dance - a practical approach,” Contemp. Theatr. Rev., vol. 11, no. 1, pp. 55-66, Jan. 2001, doi: 10.1080/10486800108568610.

[14] D. W. Hughes, "Thai Music in Java, Javanese Music in Thailand: Two Case Studies," Br. J. Ethnomusicol., vol. 1, no. 1, pp. 17-30, 1992. doi: 10.1080/09681229208567198.

[15] S. D. Humardani and A. R. Roth, "The problem of development in Javanese karawitan today," Indones. Circle. Sch. Orient. African Stud. Newsl., vol. 13, no. 37, pp. 7-13, Jun. 1985, doi: 10.1080/03062848508729610.

[16] A. Schütz, "Making Music Together: A Study in Social Relationship," in The Routledge Reader on the Sociology of Music, Routledge, 2015, pp. 73-82. doi: 10.4324/9780203736319-12

[17] B. Broening, "Alvin Lucier's I am sitting in a room1," in Analytical methods of electroacoustic music, Routledge, 2005, pp. 89-110. Available at: Google Scholar.

[18] Rustopo, Menjadi Jawa: Orang-orang Tionghua dan Kebudayaan Jawa 1895-1998. Yogyakarta: Penerbit Ombak, 2012. Availabel at: Google Scholar. 